Dariusz KASPRZAK OFMCap

(Kraków, UPJPII)

\title{
TEMATYKA SPOLECZNA W PISMACH ŚW. AMBROŻEGO Z MEDIOLANU
}

Twórczość pisarska św. Ambrożego, bpa Mediolanu (339-397) związana była przede wszystkim z jego działalnością duszpasterską. Jednym z głównych celów jego posługi biskupiej, rozpoczętej w 374 r., było przeciwdziałanie przejawom patologii społecznej, które łamiąc ewangeliczne zasady współżycia, praktycznie uniemożliwiały urzeczywistnianie ideału miłości bliźniego w życiu codziennym ${ }^{1}$. Ambroży nie napisał żadnego osobnego traktatu, gdzie całościowo rozważałby kwestie społeczne. Jednak jako biskup Mediolanu, w swej pracy na rzecz Kościoła starał się uwypuklać moralne znaczenie czynów ludzkich w kontekście ich społecznych konsekwencji. $Z$ tej racji, w większości jego pism, pojawiała się tematyka moralno-społeczna².

Motywacja tych duszpastersko-społecznych rozważań była przede wszystkim biblijna. Ambroży wskazywał na teksty z Biblii jako źródło przekazu woli Bożej oraz źródło wiedzy o człowieku i jego obowiązkach względem innych ludzi. Jego zdaniem, celem Objawienia Bożego było udoskonalenie człowieka ${ }^{3}$. W odniesieniu do kwestii moralnych ważna była dla niego także argumentacja filozoficzna, szczególnie koncepcja cnót i powinności, zaczerpnięta z dorobku rzymskiej szkoły stoickiej ${ }^{4}$. Kaznodziejski sposób przekazu Ambrożego miał charakter moralizujący i był dostosowany do codziennych wymogów bycia chrześcijaninem $\mathrm{w}$ świecie ${ }^{5}$.

\footnotetext{
${ }^{1}$ Por. R. Pankiewicz, Stosunek św. Ambrożego w „De Nabuthae” do wtasności i jatmużny, VoxP 6 (1986) t. 11, 556.

${ }^{2}$ Por. V.R. Vasey, The social ideas in the works of St. Ambrose. A study on „, De Nabuthe”, Roma 1982, 17-21.

${ }^{3}$ Ambrosius, Exameron VI 8, 31, ed. K. Schenkl - G. Banterle, SAEMO 1, Milano - Roma 19962 2 228; por. L.F. Pizzolato, La Sacra Scrittura fondamento del metodo esegetico di sant'Ambrogio, w: Ambrosius Episcopus, ed. G. Lazzati, vol. 1, Milano 1976, 396.

${ }^{4}$ Por. G. Madec, Saint Ambroise et la philosophie, Paris 1974, $23-98$ i 139-141; K. Zelzer, L'etica di sant'Ambrogio e la tradizione stoica delle virtù, w: L'etica cristiana nei secoli III e IV: eredità e confronti, SEA 53, Roma 1996, 47-56; I. Błaszczyk, Seneka o wychowaniu w rodzinie rzymskiej, Bydgoszcz 2003; P. Hadot, Twierdza wewnętrzna. Wprowadzenie do „Rozmyślań” Marka Aureliusza, thum. P. Domański, Kęty 2004, 135-242.

${ }^{5}$ Por. M. Kozera, „Suavitas sermonis” św. Ambrożego na przykładzie diatryby „, De Nabuthae
} 
Niniejszy artykuł przedstawia zarys podstawowych zagadnień społecznych, do jakich w swoich utworach odnosił się Ambroży z Mediolanu, a należy do nich tematyka małżeństwa i rodziny, pracy, prawa własności oraz cnót i wad społecznych.

\section{MAŁŻEŃSTWO I RODZINA}

Ambroży nie poświęcił osobnego dzieła zagadnieniom małżeństwa i życia rodzinnego. Pozostawił jedynie fragmentarycznie sformułowane wypowiedzi na ten temat $\mathrm{w}$ doraźnych komentarzach biblijnych oraz listach, czy też przy okazji omawiania stanów wdowieństwa czy dziewictwa. W tych zaś wypowiedziach Ambrożego, jak podkreśla Józef Naumowicz, daje się zauważyć dwie formy opinii na temat małżeństwa i rodziny - pozytywną i negatywną.

W komentarzach biblijnych oraz w poradach dotyczących małżeństwa czy rodziny biskup Mediolanu dawał przeważnie pozytywny wykład tych zagadnień. W takim ujęciu małżeństwo było dlań rzeczywistością stworzoną przez Boga oraz uświęconą i wyniesioną do godności sakramentu przez Chrystusa. Ambroży bronił w nich trwałości instytucji małżeńskiej, sprzeciwiał się rozwodom $^{7}$, mówił o równości małżonków, podkreślał ideę macierzyństwa i radość matki z dzieci ${ }^{8}$. Jako ludzka instytucja społeczna małżeństwo urzeczywistniało się nie przez pozbawienie dziewictwa (defloratio), lecz przez umowę małżeńską (pactio coniugalis) ${ }^{9}$, zgodnie z definicją Ulpiana, rzymskiego prawnika z przełomu II i III wieku, że „małżeństwo tworzy nie pożycie, lecz porozumienie" "10, choć wiele wskazuje na to, że jest to definicja późniejszego pochodzenia $^{11}$. Biskup Mediolanu przeniósł jednak tę definicję z obowiązu-

historia”, VoxP 7 (1987) z. 12-13, 237-246.

${ }^{6}$ Por. J. Naumowicz, Stosunek św. Ambrożego do matżeństwa i życia rodzinnego, VoxP 5 (1985) z. 8-9, 137-138.

${ }^{7}$ Por. Ambrosius, Expositio Evangelii secundum Lucam VIII 1-12, ed. M. Adriaen, SAEMO 12, Milano - Roma 1997, 282-292, tłum. W. Szołdrski: Wykład Ewangelii wedtug św. Łukasza, PSP 16, Warszawa 1977, 350-354.

${ }^{8}$ Por. Ambrosius, Epistula 35 (Maur. 83), ed. O. Faller, SAEMO 19, Milano - Roma 1988, 329332, thum. P. Nowak, BOK 9, Kraków 1997, 251-253; Epistula 58 (Maur. 60), SAEMO 20, 138-142, tłum. P. Nowak, BOK 20, Kraków 2003, 89-92; Epistula 62 (Maur. 19), SAEMO 20, 146-167, BOK 20, 99-113.

${ }^{9}$ Por. Ambrosius, De institutione virginis 6, 41, ed. E. Cazzaniga, SAEMO 14/2, 142: „Cum enim initiatur coniugium, tunc coniugii nomen adsciscitur; non enim defloratio virginitatis facit coniugium, sed pactio coniugalis. Denique cum iungitur puella, coniugium est, non cum virili admixtione cognoscitur” („Tytuł małżonki nabywa się, kiedy małżeństwo posiada początek, ponieważ nie utrata dziewictwa czyni małżeństwo, ale umowa małżeńska. Dlatego ma się do czynienia z małżeństwem, kiedy dziewczyna jest poślubiona, a nie kiedy została poznana przez stosunek seksualny" - przekłady tekstów Ambrożego, jeśli nie zaznaczono inaczej, pochodzą od autora artykułu).

${ }^{10}$ Ulpianus, Digesta 35, 1, 15: „Nuptias enim non concubitus sed consensus facit”.

${ }^{11}$ Por. J. Iluk, Chrześcijańskie matżeństwo i rodzina w rzymskiej starożytności, Gdańsk 1995, 
jącego wówczas prawa rzymskiego do powstającego w IV wieku prawa kościelnego, a w ten sposób sformułowaną myśl powtórzył później Augustyn z Hippony ${ }^{12}$ oraz Izydor z Sewilli ${ }^{13}$, aż wreszcie została włączona do powstałego około 1140 r. zbioru prawa kanonicznego zwanego Dekretem Gracjana ${ }^{14}$.

Natomiast pesymistyczna koncepcja kobiecości daje się zauważyć w antropologii Ambrożego, wyprowadzonej przez niego z alegoryczno-moralizującej myśli Filona $\mathrm{z}$ Aleksandrii ${ }^{15}$ oraz alegorycznych koncepcji stoickich i platońskich ${ }^{16}$. Ambroży mówi zatem m.in. o niższości kobiety i tego, co kobiece, w stosunku do mężczyzny i tego, co męskie. Pogląd o wyższości mężczyzny nad kobietą wyprowadzał z pewnych założeń filozofii greckiej,

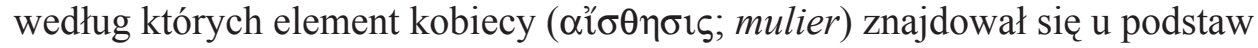
przewinień mężczyzny (vô̂s; vir). Dlatego też, kiedy prowadził rozważania o charakterze religijnym, grzech postrzegał jako poddanie się wpływowi kobiecości - poprzez przyjemność oraz otwarcie się na postrzeganie zmysłowe, a odejście od tego co męskie-umysłowe-prawne-ideologiczne:

„strzeżmy się przeto, aby owa niewiasta, to jest namiętność, sama także zwiedziona i oszukana przez przyjemność naszych zmysłów, nie pozbawiła mocy tego mężczyzny, to jest umysłu, i nie przeciagnęła go - tak usidlonego - do swoich praw i przekonań. Uciekajmy od przyjemności jak od węża. Ma ona wiele sztuczek, szczególnie w stosunku do człowieka. Bo inne istoty żyjące są zajęte chciwym poszukiwaniem pokarmu; człowiek zaś, im więcej doznaje wrażeń oczu i uszu, tym większe grożą mu niebezpieczeństwa"17.

Według takiego ujęcia antropologii ambrozjańskiej, kobieta byłaby także obdarzona mniejszą cnotliwością, w znaczeniu pierwotnej siły i otwarcia na

173; W. Osuchowski, Zarys rzymskiego prawa prywatnego, Warszawa 1971, 279.

${ }_{12}$ Por. Augustinus, De bono coniugali I 1, NBA 8/1, Roma 1978, 10, thum. W. Eborowicz, w: Pisma św. Augustyna o matżeństwie i dziewictwie. Przekład i komentarz, red. A. Eckmann, Lublin 2003, 75.

${ }^{13}$ Por. Isidorus Hispalensis, Etymologiae IX 7, 9, PL 82, 365A.

${ }^{14}$ Por. Decretum Gratiani c. 27, q. 2, c. 5.

${ }^{15}$ Por. J. Daniélou, Philon d'Alexandrie, Paris 1958, 133; R.A. Baer, Philo's use of categories male and female, Leiden 1970.

${ }^{16}$ Por. M. Spanneut, Le stö̈cisme des Pères de l'Eglise. De Clément de Rome à Clément d'Alexandrie, Paris 1957, 133-266; Madec, Saint Ambroise et la philosophie, s. 23-98, 109-132, 139-141 i 166-171.

${ }^{17}$ Ambrosius, Epistula 34 (Maur. 45), 17, SAEMO 19, 326: „Caveamus ergo, ne hominem istum, id est vôvv, mulier illa, id est passio, sensuum nostrorum delectatione et ipsa decepta atque inlusa effeminet et circumscriptum in leges suas et sententiam trahat. Fugiamus delectationem sicut serpentem. Multas artes habet et maxime in homine. Nam alia animantia cibi aviditate capiuntur, homo quanto plures sensus oculorum auriumque habet, tanto maiora pericula", thum. P. Nowak, BOK 9, 250; por. Philo Alexandrinus, De opificio mundi 59, 156, ed. L. Cohn - P. Wendland - J. Reiter, Berlin 1896, 57, tłum. L. Joachimowicz: O stworzeniu świata, w: Filon Aleksandryjski, Pisma, t. 1, Warszawa 1986, 76. 
łaskę. Mężczyzna natomiast byłby pierwszy zarówno w porządku chronologicznym (stworzony wcześniej - zdaniem Ambrożego - jeszcze przed rajem, a kobieta już w raju), oraz pierwszy w porządku charytologicznym (stworzony co prawda poza rajem, ale stał się lepszy w raju):

„«Pan Bóg wziął zatem człowieka i umieścił go w ogrodzie Eden, aby go uprawiał i doglądał». Widzisz zatem, że wziął tego, który już istniał; był bowiem na ziemi, na której został stworzony. Wzięła go zatem moc Boża, zaszczepiając mu rozwój i wzrost w cnocie ludzkiej. Umieściła go zatem w raju, oto dlaczego należy rozumieć, że mężczyzna został wzięty i jak został natchniony przez moc Bożą. Jeśli chodzi o miejsce, zwróć uwagę na to, że mężczyzna został uczyniony poza rajem, a kobieta w raju, to jest, abyś wziął pod uwagę, że nie z powodu szlachetności miejsca czy pochodzenia, lecz z powodu cnoty, każdy nabywa łaskę. Dlatego mężczyzna, ponieważ był stworzony poza rajem, czyli w miejscu pośledniejszym, okazuje się być lepszym od tej, która została stworzona w miejscu lepszym, czyli w raju, a okazuje się być niższa. Kobieta bowiem jako pierwsza została wprowadzona w błąd, i sama wprowadziła w błąd mężczyznę"18.

Dlatego mężczyzna posiadając większą moc (virtus) oraz większe otwarcie się na łaskę Bożą, może też publicznie działać jako pierwszy i strzec powierzonych sobie dóbr:

„W tym samym czasie, ponieważ mężczyzna jest pierwszy, prawie jako autor, który prowokuje płodność kobiety i do rodzenia nakłania, oraz jest bardziej widoczny w działalności publicznej, podczas gdy kobieta jest bardziej ukryta, jakby zamknięta między ścianami domu i bardziej podobna do nocy, narodzona w drugim momencie i uformowana z żebra mężczyzny, dłużniczka daru stworzenia wobec tego, który ją poprzedził, podporządkowana także przywilejowi liczby większej wagi ze względu na użyteczność rodzenia"19.

${ }^{18}$ Ambrosius, De paradiso 24, ed. C. Schenk1, SAEMO 2/1, 66-68: „«Et adprehendit Deus hominem, quem fecit, et posuit eum in paradiso operari et custodire». Vides quoniam qui erat adprehenditur; erat autem in terra plasmationis suae. Adprehendit ergo eum virtus Dei inspirans processus et incrementa virtutis. Denique in paradiso eum conlocavit, ut scias adprehensum quasi adflatum divina esse virtute. Quo loci illud adverte quia extra paradisum vir factus est et mulier intra paradisum, ut advertas quod non loci, non generis nobilitate, sed virtute unusquisque gratiam sibi conparat. Denique extra paradisum factus, hoc est in inferior loco vir melior invenitur et illa quae in meliore loco hoc est in paradiso facta est interior repperitur; mulier enim prior recepta est et virum ipsa decepit". Więcej na temat koncepcji tzw. podwójnej kreacji człowieka, jaka miałaby miejsce w dwóch różnych miejscach zob. C. Morino, Il ritorno al Paradiso di Adamo in S. Ambrogio. Itinerario spirituale, Città del Vaticano 1952, 37. Odnośnie zaś obecnej w tym tekście koncepcji dwóch różnych elementów, kobiecego i męskiego, które wspólnie tworzą człowieka, por. B. Maes, La loi naturelle selon Ambroise de Milan, Roma 1967, 66-70; A. Loiselle, Natura de l'homme et histoire du salut. Étude de l'anthropologie d'Ambroise de Milan, Lyon 1970, 16-20.

${ }^{19}$ Ambrosius, De Noe 13, 43, ed. C. Schenk1, SAEMO 2/1, 408: „simul quia vir prior quasi 
Zdaniem Luigiego Franco Pizzolato, Ambroży nie przesądzał nigdzie o wyższości ontologicznej mężczyzny wobec kobiety, ale z powyższych jego wypowiedzi wyłania się zdecydowanie koncepcja wyższości funkcjonalnej tego co

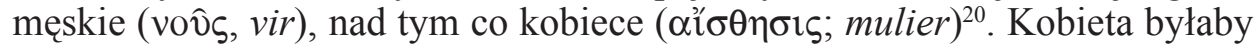
zatem stworzona jako pomoc dla mężczyzny; liczy ona na wsparcie z jego strony, ponieważ on jest jej głową. Płeć żeńska jest zatem niższa, zależna od męskiej i wiedzie mężczyzn do upadku ${ }^{21}$. Natomiast swoista emancypacja natury kobiecej następowała, zdaniem Ambrożego, dzięki chrześcijańskiej koncepcji soteriologii, szczególnie na płaszczyźnie edukacji religijnej, w środowisku małżeńskim i rodzinnym oraz w stanie dziewictwa konsekrowanego ${ }^{22}$.

Ambroży także w pismach, poświęconych dziewictwu konsekrowanemu, podawał często negatywny wykład dotyczący małżeństwa, chcąc kaznodziejsko, w formie pochwał i zachęt, przekonać do wytrwania w czystości. Dlatego też retorycznie przerysowywał stan przeciwny dziewictwu jako bezwartościowy, szkodliwy, a nawet haniebny. Toteż małżeństwo w pismach do dziewic było niekiedy ukazywane przez niego za pomocą pejoratywnych obrazów jarzma, czy kajdan, uznawane za ograniczenie wolności i przeszkodę w zjednoczeniu z Bogiem, instytucję dla słabszych oraz jako lekarstwo na pożądliwość. Należy jednak zaznaczyć, że pism o dziewictwie biskup Mediolanu nie kierował do ogółu wiernych, ale wyłącznie do dziewic. Jego zatem właściwe poglądy na temat małżeństwa i rodziny należy rekonstruować na podstawie jego okazjonalnych wypowiedzi pozytywnie ujmujących te instytucje. Przy czym ta koncepcja małżeństwa i rodziny pozostaje wielce dialektyczna, w zależności od rodzaju dyskursu, jaki w danym dziele aktualnie prowadził ${ }^{23}$. Dlatego też udzielając okolicznościowych porad chwalił małżeństwo i rodzinę, natomiast $\mathrm{w}$ retorycznie już wypracowanych traktatach promujących dziewictwo, ukazywał je w negatywnym świetle, jako instytucje przeznaczone dla słabszych duchowo.

\footnotetext{
auctor, qui virtutem moveat mulieris atque in partus excitet, actu ille clarior publico, ista obscurior tamquam domesticis clausa parietibus et nocti proxima, secundo orta loco et creationis suae formata in costa viri debens gratami superiori, numeri quoque potioris obnoxia privilegio et pariendi usu materialibus comparanda".

${ }^{20}$ Por. L.F. Pizzolato, La coppia umana in sant'Ambrogio, w: Etica sessuale e matrimonio nel cristianesimo delle origini, ed. R. Cantalamessa, Studia Patristica Mediolanensia 5, Milano 1976, 185; M. Sciatella, Dio, l'anima e l'uomo nell'antropologia teologica di S. Ambrogio, „Divinitas” 34 (1990) 172-178.

${ }^{21}$ Ambrosius, De paradiso 4, 24, SAEMO 2/1, 68: „Nam ecce illa quae in adiumentum facta est viro praesidio virili indiget quia vir caput est mulieris, ille autem qui adiumentum uxoris habiturum se esse credebat lapsus est per uxorem” (,ta bowiem, która została stworzona jako pomoc mężczyźnie, potrzebuje męskiego wsparcia, ponieważ mąż jest głową kobiety, ten zaś, który uważał, że będzie miał pomoc ze strony żony, upadł z winy żony").

${ }^{22}$ Por. Pizzolato, La coppia umana in sant'Ambrogio, s. 181-182.

${ }^{23}$ Por. Naumowicz, Stosunek św. Ambrożego do matżeństwa, s. 138-139; tenże, Wyrażenia na oznaczenie matżeństwa u św. Ambrożego, mps BKUL, Lublin 1980.
} 


\section{PRACA LUDZKA}

Także na temat pracy ludzkiej Ambroży nie napisał oddzielnego traktatu. Niemniej w swoich pismach odnosił się do niej okazjonalnie, jako działania koniecznego do zaspokojenia podstawowych potrzeb człowieka, narzędzia zbawienia oraz środka do osiągnięcia cnót moralnych ${ }^{24}$. Ambrozjańska koncepcja pracy zależała od jego alegorycznego sposobu komentowania Biblii, w tym także od biblijnych komentarzy Filona z Aleksandrii ${ }^{25}$ oraz duchowego interpretowania wszelkiej działalności człowieka ${ }^{26}$.

Zdaniem biskupa Mediolanu, praca przynależy do życia ludzkiego od momentu stworzenia człowieka, gdyż jeszcze przed popełnieniem grzechu pierwszy człowiek pracował w raju, a praca ta była dla niego powodem do radości i zadowolenia ${ }^{27}$. Ambroży rozważając Rdz 2, 15 stwierdzał za tekstem biblijnym, że celem działalności Adama w raju była praca w ogrodzie rajskim oraz strzeżenie go. Wyjaśniając te pojęcia stosował alegorezę, mówiąc, że praca ta oznaczała postęp $\mathrm{w}$ cnotach, natomiast strzeżenie ogrodu należałoby rozumieć jako pracę na rzecz ogrodu, co też tłumaczył jako poszukiwanie rzeczy nowych oraz pilnowanie rzeczy już otrzymanych ${ }^{28}$. Praca Adama jako pierwszego człowieka stała się też przykładem pracy dla kolejnych pokoleń ludzkich, które mają powierzony od Boga obowiązek doglądania i uprawy dóbr sobie powierzonych ${ }^{29}$.

Natomiast po popełnieniu grzechu przez pierwszych ludzi, w myśl Rdz 3, 17-19, zmienił się także stosunek człowieka do pracy, w świecie upadłym po grzechu owocem pracy stał się już trud i ból, gdyż przez grzech człowiek przekroczył ustalony przez Boga pierwotny, idealny porządek rzeczy ${ }^{30}$; praca stała się zatem nie tylko karą za winy ${ }^{31}$, ale także sposobem postępowania na drodze do odkupienia win $^{32}$. Poza rajem praca człowieka oraz związany z nią trud i pot, stały się też aktywnością zapewniającą człowiekowi pożywienie ${ }^{33}$. Jak zauważa Antonio V. Nazzaro, według Ambrożego, praca ludzka także po

${ }^{24}$ Por. G.D. Gordini, Il lavoro secondo S. Ambrogio, „Ambrosius” 34 (1958) 80-95.

${ }^{25}$ Por. H. Savon, Saint Ambroise devant l'exégèse de Philon le Juif, Paris 1977; A.V. Nazzaro, Il lavoro nei motivi esegetici di Ambrogio, w: Spiritualità del lavoro nella catechesi dei Padri del III-IV secolo, ed. S. Felici, Biblioteca di Scienze Religiose 75, Roma 1989, 79-93.

${ }^{26}$ Por. A. Bonato, Concezione del lavoro nella spiritualità di sant'Ambrogio, w: Dizionario di spiritualità biblico-patristica 35, Roma 2003, 194-245.

${ }^{27}$ Por. Ambrosius, Explanatio Psalmi 36, 20, ed. M. Petschenig, SAEMO 7, Milano - Roma 1980, 174.

${ }^{28}$ Por. Ambrosius, De paradiso 4, 25, SAEMO 2/1, 68.

${ }^{29}$ Por. tamże 11, 51, SAEMO 2/1, 118.

${ }^{30}$ Por. Ambrosius, Exaemeron III 10, 45, SAEMO 1, 156-158.

${ }^{31}$ Por. Ambrosius, De Iacob et vita beata I 2, 24, ed. C. Schenk1, SAEMO 3, Milano - Roma 1982, 254.

${ }^{32}$ Por. Ambrosius, De paradiso 15, 75, SAEMO 2/1, 162-164.

${ }^{33}$ Por. tamże 15, 77, SAEMO 2/1, 164. 
grzechu miała być czynnością racjonalną oraz czynnikiem rozwoju społeczności ${ }^{34}$. Natomiast w duchowo-alegorycznej interpretacji Rdz 3, 17 w kluczu Pawłowych tekstów z Rz 7, 23 oraz 1 Kor 9, 11 i 27 wspomniana praca i pot oznaczały dla Ambrożego także ciężką fatygę ciała oraz ascetyczny trud duszy, przy czym ten drugi byłby ważniejszy niż trud cielesny ${ }^{35}$.

Człowiek, jako stworzony na Boży obraz, jest zawsze interpretatorem i naśladowcą Boga, dlatego także w swojej pracy winien naśladować Stworzyciela według swoich możliwości ${ }^{36}$. Bóg podjął pracę w dziele stworzenia, odkupienia oraz uświęcenia człowieka ${ }^{37}$. Człowiek został od początku wezwany przez Niego do przekształcania ziemi i czynienia jej sobie poddana, aby polepszać własną pozycję życiową, stąd żaden człowiek nie powinien uciekać od pracy ${ }^{38}$, a ona sama winna być efektywna i owocna ${ }^{39}$; praca nie może być bezużyteczna, dlatego powinna być wykonywana według cnót i zawsze w odniesieniu do $\mathrm{Boga}^{40}$.

Obowiązek pracy, jako wypełnianie zalecenia Bożego, stanowił obok modlitwy i studiowania Biblii jeden z elementów konstytutywnych życia monastycznego w Italii IV i $\mathrm{V}$ wieku ${ }^{41}$. Ambroży, w duchu tych wskazań monastycznych, wskazywał na wymóg pracy, nauki i modlitwy mnichów ${ }^{42}$ oraz dziewic konsekrowanych ${ }^{43}$. W pracy osobom konsekrowanym Biskup Mediolanu zalecał umiarkowanie i stosowne wyważenie działań, według zdolności, wieku, wolnej woli oraz konieczności wymaganego odpoczynku ${ }^{44}$. Modelami pracy wydajnej i mądrej były dla Ambrożego niektóre postaci biblijne. Nasz

${ }^{34}$ Por. Ambrosius, Expositio Evangelii secundum Lucam, Prologus 6, SAEMO 11, 86, PSP 16, 20; zob. Nazzaro, Il lavoro nei motivi esegetici di Ambrogio, s. 82.

${ }^{35}$ Por. Ambrosius, Explanatio Psalmi 37, 33, SAEMO 7, 294.

${ }^{36}$ Por. Ambrosius, Exameron I 7, 27, SAEMO 1, 58; więcej na ten temat zob. A. Bonato, Dio nel pensiero di Ambrogio, w: Dizionario di spiritualità biblico-patristica, vol. 14: Dio nei Padri della Chiesa, Roma 1996, 207-256; G. Bentivegna, Lo Spirito Santo nella vita della Chiesa secondo sant'Ambrogio, „Civiltà Cattolica” 148 (1997) 259-271; A. Bonato, La figura di Cristo in sant'Ambrogio, „Teologia” 3 (1997) 244-290; tenże, L'economia di Cristo Salvatore negli scritti di Ambrogio, w: Dizionario di spiritualità biblico-patristica, vol. 25: Gesù Cristo nei Padri della Chiesa (IV-V secolo), Roma 2000, 128-182.

${ }^{37}$ Por. Ambrosius, Exameron I 4, 12; I 5, 19; I 6, 22, SAEMO 1, 34-36, $42-44$ i 46-50; De Cain et Abel I 8, 32, SAEMO 2/1, 228.

${ }^{38}$ Por. Ambrosius, Expositio Psalmi 118, 10, 8, SAEMO 9, 406.

${ }^{39}$ Por. Ambrosius, De Cain et Abel I 4, 12, SAEMO 2/1, 192-194; II 28, SAEMO 2/1, 260; Expositio Psalmi 118, 8, 13, SAEMO 9, 320.

${ }^{40}$ Por. Ambrosius, De Cain et Abel II 2, 9, SAEMO 2/1, 260.

${ }^{41}$ Por. A. Quacquarelli, Lavoro e ascesi nel monachesimo prebenedittino del IV e V secolo, Bari 1982, 69-70.

${ }^{42}$ Por. Ambrosius, Epistula 14 extra collectionem (Maur. 63), 82, ed. M. Zelzer, SAEMO 21, Milano - Roma 1988, 304.

${ }^{43}$ Por. Ambrosius, De virginibus I 11, 60, ed. E. Cazzaniga, SAEMO 14/1, Milano - Roma $1989,158$.

${ }^{44}$ Por. tamże III 4, 16-17, SAEMO 14/1, 220-222; De viduis 11, 70-71, SAEMO 14/1, 302. 
Biskup wymieniał i wzywał do naśladowania przykładu Jakuba, będącego dla niego przykładem człowieka rozsądnego i pracowitego, dlatego też błogosławionego przez Boga ${ }^{45}$, a także Mojżesza, sprawiedliwie wypełniającego pracę wyzwolenia ludu z niewoli ${ }^{46}$, czy wreszcie Pawła Apostoła, niestrudzonego głosiciela Bożego zbawienia i miłosierdzia ${ }^{47}$.

Antonio V. Nazzaro zauważa, że Ambroży zdecydowanie podkreślał wartość pracy fizycznej i wykonywanej własnoręcznie, w przeciwieństwie do autorów pogańskich, którzy tego rodzaju aktywność deprecjonowali oraz zaliczali do zakresu posług niewolników i robotników najemnych. Znaczenie takiej pracy dowartościował bowiem sam Jezus Chrystus, który sam pracował zarówno intelektualnie jak i manualnie, dlatego też w chrześcijaństwie ceniono każdy rodzaj pracy intelektualnej czy manualnej, natomiast bezczynność i lenistwo były potępiane ${ }^{48}$. Wpływ powyższej refleksji chrześcijańskiej jest widoczny w ówczesnym ustawodawstwie cesarskim, które od IV wieku docenia pracę fizyczną i manualną, wykonywaną również przez ludzi wolnych, pracujących za wynagrodzeniem, na podstawie umowy z pracodawcą. Prawa cesarskie podkreślają tutaj konieczność wynagrodzenia pracownika za wykonaną pracę ${ }^{49}$.

Ambroży przekazywał tę myśl w swoich pismach, kiedy oprócz zwyczajowych zachęt do pracy ręcznej, polecał także pokorną pracę intelektualną ${ }^{50}$ czy apostolską ${ }^{51}$ oraz bronił prawa pracownika do sprawiedliwej zapłaty ${ }^{52}$. Napominał też, aby pracodawca $\mathrm{w}$ obawie przed niechęcią pracownika nie przedłużał jego pracy i związanego $\mathrm{z}$ tym trudu, ponieważ to $\mathrm{z}$ kolei rodzi jego arogancję ${ }^{53}$. Dlatego praca ludzka winna być działaniem solidarnym, zespołowym, zmierzającym do dobra wszystkich, czego symboliczny przykład stanowiło współdziałanie pszczół na rzecz ula ${ }^{54}$. Motyw pracy pszczół, jako wzór pracowitości i solidarności na rzecz dobra wspólnego, był u Ambrożego ewidentnym toposem literackim, zapożyczonym od Wergiliusza i dostosowanym do opisu społeczności IV/V wieku ${ }^{55}$.

\footnotetext{
${ }^{45}$ Por. Ambrosius, De institutione virginis 100-101, SAEMO 14/2, 180-182.

${ }^{46}$ Por. Ambrosius, Exameron I 2, 6, SAEMO 1, 28.

${ }^{47}$ Por. Ambrosius, De patriarchis 12, 58, ed. C. Schenkl, SAEMO 4, Milano - Roma 1980, 66.

${ }^{48}$ Por. Nazzaro, Il lavoro nei motivi esegetici di Ambrogio, s. 88.

${ }^{49}$ Por. B. Biondi, Il diritto romano cristiano, II, Milano 1952, 363-372.

${ }^{50}$ Por. Ambrosius, De Cain et Abel II 1, 3-4, SAEMO 2/1, 250-252; Expositio Psalmi 118, 9, 19 , SAEMO 9, 394.

${ }^{51}$ Por. Ambrosius, Epistula 20 (Maur. 77), 7, SAEMO 19, 206; Explanatio Psalmi 36, 43, SAEMO 7, 200-203; De officiis I 32, 165, ed. I.G. Krabinger, SAEMO 13, Milano - Roma 1991², 122-124, tłum. K. Abgarowicz: Św. Ambroży, Obowiqzki duchownych, Warszawa 1967, 78.

${ }^{52}$ Por. Ambrosius, Epistula 36 (Maur. 2), 12, SAEMO 19, 28-30; Epistula 62 (Maur. 19), 3 , SAEMO 20, 146; De officiis III 3, 20, SAEMO 13, 284-286; De Nabuthae 5, 20, ed. C. Schenk1, SAEMO 6, Milano - Roma 1985, 142-144; tamże 13, 54, SAEMO 6, 174.

${ }^{53}$ Por. Ambrosius, Exameron V 15, 50-52, SAEMO 1, 300-302.

${ }^{54}$ Por. tamże V 21, 67, SAEMO 1, 318.

${ }^{55}$ Por. L. Ruggini, Il vescovo Ambrogio e la Historia Augusta. Attualità di un topos politico-
} 


\section{PRAWO WŁASNOŚCI}

Ambroży był daleki od potępiania prawa do posiadania własności prywatnej, co widać już w jego pierwszych dziełach, jak np. w mowie żałobnej $O \dot{z} y$ ciu brata Satyra, gdzie naucza o zachowaniu niepodzielności ojcowskiego mienia $^{56}$. Człowiek żyjący w doczesności ma pełne prawo do posiadania i dysponowania własnym majątkiem, w tym także do motywowanej religijnymi względami jego sprzedaży i rozdania ubogim uzyskanych w ten sposób pieniędzy ${ }^{57}$. Człowiek na ziemi nie cieszy się jednak nieograniczonym prawem posiadania, lecz powinien zarządzać swoim bogactwem jako odpowiedzialny rządca $^{58}$.

Zdaniem Ambrożego, źródłem wszelkiego dobra jest Bóg, a dobra materialne mają zastosowanie według intencji ich Stwórcy, czyli są przeznaczone dla wszystkich ludzi ${ }^{59}$. Biskup Mediolanu dzielił dobra, jakimi dysponuje człowiek, na dobra duszy, ciała, oraz dobra zewnętrzne. Dwa pierwsze rodzaje dóbr są przeznaczone na wyłączne posiadanie człowieka, natomiast dobrami zewnętrznymi, czyli materialnymi, człowiek ma zarządzać rozsądnie, tak aby dojść do zbawienia. $Z$ nich człowiek ma zaspokajać nie tylko potrzeby własne, ale i wspierać potrzebujących ${ }^{60}$. Dobra materialne mają być administrowane indywidualnie, według kryterium prawa Bożego, a nie żądzy posiadania czy namiętności ${ }^{61}$.

Zdaniem Ambrożego, dobra materialne mają uniwersalne przeznaczenie dla wszystkich ludzi, gdyż ich źródłem jest Bóg. Stąd też winny być gospodarowane przez wszystkich ludzi zgodnie z ideami sprawiedliwości, braterstwa, solidarności i wzajemnej ludzkiej miłości ${ }^{2}$. Człowiek bogaty powinien być

letterario, w: Atti del Colloquio Patavino sulla Historia Augusta, Roma 1963, 67-79; L. Alfonsi, L'ecphrasis ambrosiana del «libro delle api» vergiliano, VetCh 2 (1965) 129-138.

${ }^{56}$ Por. Ambrosius, De excessu fratris 1, 7, ed. O. Faller, SAEMO 18, Milano - Roma 1985, 28, thum. J. Czuj, POK 21, 109.

${ }^{57}$ Por. Ambrosius, Epistula 58 (Maur. 60), 1-2, SAEMO 20, 138-140, BOK 9, 197-198.

${ }^{58}$ Por. Ambrosius, Epistula 36 (Maur. 2), 12, SAEMO 20, 28-30, BOK 20, 11-12; Epistula 73 (Maur. 18), 3 i 11-21, SAEMO 21, 62 i 68-76.

${ }^{59}$ Por. Ambrosius, Expositio Evangelii secundum Lucam VII 124 i 246, SAEMO 12, 184 i 278 , PSP 16, 299-300 i 348-349; De Nabuthae 1, 2, SAEMO 6, 130-132, thum. R. Pankiewicz, PSP 35, Warszawa 1986, 26-27.

${ }^{60}$ Por. H. Gulbinowicz, Etyczne poglady św. Ambrożego na dobra materialne i prawo własności, „Studia Warmińskie” 1 (1964) 264-265; zob. Ambrosius, De Nabuthae 7, 37, SAEMO 6, 158, PSP 35, 38.

${ }^{61}$ Por. Ambrosius, De Nabuthae 3, 11, SAEMO 6, 138, PSP 35, 29; zob. tamże 5, 21-25; tenże, De officiis ministrorum I 16, 62-63, thum. Abgarowicz, s. 42.

${ }^{62}$ Por. Ambrosius, De officiis ministrorum I 28, 132, SAEMO 13, 102-104, thum. Abgarowicz, s. 66; De Nabuthae 12, 53, SAEMO 6, 172, PSP 35, 44-45; tamże 1, 2, SAEMO 6, 130-132, PSP 35, 26-27; tamże 3, 12, SAEMO 6, 138-140, PSP 35, 26-27; zob. M.G. Mara, The notion of solidarity in St. Ambrose's teaching on creation, sin and redemption, Roma 1967. 
cały czas świadomy, że jest tylko ziemskim administratorem powierzonych mu przez Boga dóbr, do których powinien dochodzić uczciwie i sprawiedliwie nimi zarządzać ${ }^{63}$. Sama ziemia jest powierzona człowiekowi tylko w doczesne zarządzanie, dlatego winien on się o nią troszczyćc ${ }^{64}$, a zanieczyszczanie środowiska naturalnego jest przestępstwem ${ }^{65}$. Dobra materialne mają zaspokajać potrzeby materialne człowieka w życiu doczesnym (jedzenie, ubranie, mieszkanie $)^{66}$; mogą być dziedziczone, a możliwość dziedziczenia dóbr pieniężnych rodziców przez dzieci wzmaga szacunek tych ostatnich dla rodziców, gdyż krnąbrne dzieci mogą być wydziedziczone z majątku ${ }^{67}$. Dobra materialne mają pokryć tak zwane potrzeby konieczne człowieka, natomiast ich nadmiar powinien służyć pomocy biedniejszym i chorym oraz gościnności ${ }^{68}$.

Kościół jako instytucja również ma prawo do posiadania własności prywatnej i zarządzania nią, zwłaszcza w celu wspomagania potrzebujących z dóbr kościelnych ${ }^{69}$. Ambroży podkreślał prawo Kościoła, jako organizacji religijnej, do indywidualnego posiadania miejsc kultu, co jest zagwarantowane zarówno ludzkim prawem stanowionym, jak i prawem Bożym ${ }^{70}$. W konflikcie z innowiercami, czy z samym cesarzem, biskup nie ma prawa oddawania tym pierwszym posiadanego przez Kościół katolicki budynku świątyni ${ }^{71}$, ponieważ jako dom Boży, przynależy on przede wszystkim do Boga, natomiast własność prywatna Ambrożego jako biskupa, przynależy do ubogich ${ }^{72}$. Kościół ma obowiązek płacić podatki władzy, lecz budynki kościelne nie mogą być oddawane władzy cesarskiej, ponieważ świątynia Boża przynależy już do Boga i jego ziemskiej wspólnoty, i dlatego nie należy do jurysdykcji cesarskiej ${ }^{73}$. Stąd też Ambroży

${ }^{63}$ Por. Ambrosius, De excessu fratris 1, 55-60, SAEMO 18, 60, POK 21, 128.

${ }^{64}$ Por. Ambrosius, Exameron V 3, 9, SAEMO 1, 246, PSP 4, 144; o wpływie homilii moralnych Bazylego Wielkiego na myśl Ambrożego zob. R. Andrzejewski, Myśl społeczna św. Bazylego Wielkiego w nauce św. Ambrożego, RTK 27 (1980) z. 4, 179-182; L.J. Swift, Basil and Ambrose on the six days of creation, „Augustinianium” 21 (1981) 317-328.

${ }^{65}$ Por. E. Osek, Wypowiedzi św. Ambrożego przeciwko dewastacji ziemi, VoxP 18 (1998) t. 3435, 183-194.

${ }^{66}$ Por. Ambrosius, Expositio Evangelii secundum Lucam VII 245, SAEMO 12, 276, PSP 16, 348; tenże, Exameron VI 7, 42.

${ }^{67}$ Por. Ambrosius, Epistula 20 (Maur. 77), 1, SAEMO 19, 202, BOK 9, 160.

${ }^{68}$ Por. Ambrosius, Epistula 62 (Maur. 19), 6, SAEMO 20, 148, BOK 20, 100-101; De Nabuthae 13, 57, SAEMO 6, 176-178, PSP 35, 46-47; De officiis II 21, 108, SAEMO 13, 244, thum. Abgarowicz, s. 148; tamże III 6, 37, SAEMO 16, 296, tłum. Abgarowicz, s. 177.

${ }^{69}$ Por. K. Gurda, Wspomaganie ubogich i potrzebujacych $w$ Kościele mediolańskim za czasów św. Ambrożego, VoxP 16 (1996) z. 30-31, 151-159.

${ }^{70}$ Por. Ambrosius, Epistula 76 (Maur. 20), 19, SAEMO 21, 146.

${ }^{71}$ Por. Ambrosius, Epistula 76 (Maur. 20), 2, SAEMO 21, 138.

${ }^{72}$ Por. Ambrosius, Epistula 76 (Maur. 20), 8, SAEMO 21, 140: „quamquam omnia, quae mea sunt, essent pauperum, verum ea quae divina imperatoriae potestati non esse subiecta".

${ }^{73}$ Por. Ambrosius, Epistula 75a (Maur. 21), 35, SAEMO 21, 134. 
wyprowadzał swój słynny wniosek, dotyczący w szczególności wierzących władców, iż „,cesarz bowiem jest w Kościele, nie ponad Kościołem”74.

Ambroży nie stworzył własnych zasad korzystania z dóbr materialnych, głosił tylko bardziej zdecydowanie niż inni biskupi, ideę prymatu osoby nad rzeczą, prawo do korzystania z dóbr materialnych na zasadzie miłości bliźniego oraz opieki nad ludźmi słabymi i ubogimi ${ }^{75}$. Uznając prawo jednostki czy instytucji do indywidualnego posiadania i zarządzania majątkiem, Mediolańczyk wskazywał na odpowiedzialny zarząd bogactwem, wynikający z motywacji religijnej. Ograniczenia ludzkiego prawa do posiadania, wynikały z chrześcijańskiego pojmowania Boga, jako źródła wszelkich bogactw oraz celu życia ludzkiego, jakim jest zbawienie w Bogu. Aby chrześcijanin spójnie dążył do celu ostatecznego, dobra materialne powinny być w doczesności administrowane według kryteriów prawa Bożego, a nie ludzkich namiętności.

\section{CNOTY I WADY SPOŁECZNE}

Ambroży z Mediolanu był najprawdopodobniej pierwszym autorem chrześcijańskim, który wprowadził do teologii moralnej syntezę nauki o cnotach, zaczerpniętą z tradycji etyki stoickiej ${ }^{76}$. Filozofia stoicka bowiem od II w. prz. Chr. przyjęła się bardzo dobrze w środowisku rzymskim. Za jej założyciela uważa się Panajtiosa z Rodos (185-110 prz. Chr.), którego traktat na temat obowiązków ${ }^{77}$ stał się inspiracją dla Cycerona (106-43 prz. Chr.) i jego De officiis, na których z kolei wzorował się Ambroży, pisząc swoje De officiis ministrorum. Według stoików, cnota sama, bez pomocy tzw. dóbr zewnętrznych (typowych dla filozofii arystotelesowskiej) prowadzi człowieka do życia szczęśliwego, wskutek czego powinna być uważana za jedyne prawdziwe dobro. Do powyższej idei stoicy dodawali jeszcze drugą tezę, że każdy człowiek posiada fundamentalną potrzebę doskonalenia się moralnego poprzez życie cnotliwe, według podstawowych potrzeb, podporządkowanych czterem cnotom fundamentalnym, o których mówił wcześniej Platon. Ambroży połączył ten schemat stoicko-platoński z alegoryczną koncepcją cnót Filona z Aleksandrii (według którego cztery rzeki prowadzące do raju to symbol cnót kardynalnych) oraz teologią moralnego doskonalenia się w ujęciu św. Pawła Apostoła ${ }^{78}$.

${ }^{74}$ Ambrosius, Epistula 75a (Maur. 21), 36, SAEMO 21, 136: „imperator enim intra ecclesiam non supra ecclesiam est”; por. M. Zelzer, ,Imperator intra ecclesiam non supra ecclesiam est” (Ambrosius, Epistula 75a, 36), VoxP 18 (1998) t. 34-35, 219-226.

${ }^{75}$ Por. Pankiewicz, Stosunek św. Ambrożego do własności, s. 565-566.

${ }^{76}$ Por. P. Cirsis, Ennoblement of pagan virtues, Roma 1955; F.E. Consolino, L',,optimus princeps" secondo s. Ambrogio: virtù imperatorie e virtù cristiane nelle orazioni funebri per Valentiniano e Teodosio, „Rivista Storica Italiana” 96 (1984) 1025-1045; P. Daubercies, Les avatars de la vertu, „Mélanges de Science Religieuse » 44 (1987) 89-107; Zelzer, L'etica di Sant'Ambrogio, s. 47-56.

${ }^{77}$ Por. G. Reale, Historia filozofii starożytnej, t. 3, tłum. I. Zieliński, Lublin 2004, 439-448.

${ }^{78}$ Por. Madec, Saint Ambroise et la philosophie, s. 200-214; Zelzer, L'etica di Sant'Ambrogio, 
Podstawową cnotą dla Ambrożego była jednak pokora, obca filozofii pogańskiej, za to fundamentalna dla etyki chrześcijańskiej. Poprzez pokorę i bojaźń Bożą chrześcijanin, zdaniem Ambrożego, może dojść do właściwej mądrości i błogosławieństwa oraz szczęścia, to jest poznania Boga i życia wiecznego ${ }^{79}$. Na tej drodze do Boga i szczęścia wiecznego chrześcijanin powinien żyć także według szeregu cnót, które posiadają ewidentne znaczenie społeczne: obowiązkowości, milczenia, wolności, cnót kardynalnych (roztropności, sprawiedliwości, męstwa, umiarkowania), pożyteczności, uczciwości, udzielania jałmużny. $Z$ wad społecznych natomiast Ambroży przestrzegał szczególnie przed popadaniem w egoizm, pychę, chciwość, lichwę, popełnianiem niegodziwości oraz przed obiecywaniem spełnienia złych/nieroztropnych czynów.

1. Cnoty społeczne: • obowiązkowość, związana z pojęciem obowiązku (officium $)^{80}$, zdaniem Ambrożego, wywodzi się z filozofii greckiej, ale jest obecna także i w Piśmie Świętym ${ }^{81}$. Obowiązek, w ujęciu chrześcijańskim, wypływa $\mathrm{z}$ tego, co jest moralnie dobre i pożyteczne, co ma odniesienie do życia wiecznego ${ }^{82}$ i to co przystoi czynić (decorum) ${ }^{83}$; Ambroży za Cyceronem stwierdza, że w zakres tego terminu wchodzi porządek/karność oraz wytworność, wyklucza natomiast z zakresu tego pojęcia cyceroniańskie piękno cielesne oraz siłę fizyczną ${ }^{84}$. Dzieli obowiązki na zwyczajne (wypełnianie przykazań) i doskonałe (naśladowanie Jezusa w wyrzeczeniu i wypełnianiu prawa Ewangelii, miłość nieprzyjaciół, modlitwa za oszczerców i prześladowców, miłosierdzie wobec ludzi, szczególnie tych potrzebujących) ${ }^{85}$. Młodzieży zaleca jako obowiązek życie w czystości, w bojaźni Bożej oraz wyrabianie innych cnót, zwłaszcza skromności ${ }^{86}$. Wszystkim zaleca skromność i wstydliwość, unikanie gniewu i namiętności ${ }^{87}$. Podstawą dobrego czynu jest, jego

s. 48-50; A.V. Nazzaro, Ambrogio e Paolo (Ambr. „vid”. 13, 79), w: Filologia antica e moderna. Due giornate di studio su tradizione e critica dei testi, ed. A. Roselli, Soveria Mannelli 1997, 79-90; W. Turek, Paolo maestro di vita spirituale nelle „Lettere” di Ambrogio, w: Atti del V Simposio di Tarso su S. Paolo apostolo, Turchia: la Chiesa e la sua storia 12, ed. L. Padovese, Roma 1998, 269279; zob. Philo Alexandrinus, Allegoriae legum 63-87, tenże, De virtutibus, tłum. L. Joachimowicz: Filon Aleksandryjski, Pisma, Warszawa 1986, 100-106 i 231-275.

${ }^{79}$ Zelzer, L'etica di sant'Ambrogio, 51-53.

${ }^{80}$ Etymologicznie bp Mediolanu próbował wiązać termin officium z pojęciem efficere (przynosić korzyść), czego jednak z punktu widzenia językoznawstwa nie da się utrzymać, gdyż, jak zaznacza K. Abgarowicz (Św. Ambroży z Mediolanu, Obowiqzki duchownych, s. 28, n. 30), „nauka wywodzi ten wyraz z opifacium (pełnienie służby); por. wyraz opifex (robotnik, rzemieślnik)”.

${ }^{81}$ Por. Ambrosius, De officiis ministrorum I 8, 25-26, SAEMO 13, 36-38, thum. Abgarowicz, s. 28.

${ }^{82}$ Por. tamże I 9, 27-28, SAEMO 13, 38, thum. Abgarowicz, s. 29-30.

${ }^{83}$ Por. tamże I 10, 30-31, SAEMO 13, 40-41, thum. Abgarowicz, s. 31-32.

${ }^{84}$ Por. tamże I 19, 81-84, SAEMO 13, 72-74, thum. Abgarowicz, s. 48-49.

${ }^{85}$ Por. tamże I 11, 36-38, SAEMO 13, 44, thum. Abgarowicz, s. 32-33.

${ }^{86}$ Por. tamże I 17, 65-66 i I 18, 67-80, SAEMO 13, 62-64 i 64-72, thum. Abgarowicz, s. 43 i 44-48.

${ }^{87}$ Por. tamże I 5, 20-22, SAEMO 13, 32-34, thum. Abgarowicz, s. 49-55. 
zdaniem, zachowanie w postępowaniu trzech postulatów: pożądania/namiętności powinny być podporządkowane rozumowi, w gorliwości winien być zachowany umiar stosownie do wagi sprawy, a dążenie i działanie powinien cechować umiar i przestrzeganie kolejności spraw ${ }^{88}$.

- milczenie, zalecane przez Ambrożego jako cnota społeczna, gdyż zabezpiecza przed grzechem i nierozważnie wypowiedzianym słowem ${ }^{89}$; milczenie, aby było cnotą w społeczeństwie, nie może być bierne ani stałe, kiedy bowiem istnieje konieczność, należy mówić ${ }^{90}$, słowa jednak powinny być nacechowane umiarem, godnością myśli oraz powagą wypowiedzi ${ }^{91}$; umiar i ostrożność, także w słowach, wyrabiają cnoty godności i skromności ${ }^{92}$, te zaś z kolei powstrzymują człowieka od gwałtownych słów i ulegania nieuporządkowanym namiętnościom ${ }^{93}$; milczenie powinno się zachować szczególnie wobec przeciwnika, gdyż, zdaniem Ambrożego, w ten sposób uzyskuje się nad osobą wrogą swoistą przewagę moralną, a jednocześnie zachowuje pokorę, będącą cnotą wymaganą wobec wszystkich ludzi $i^{94}$; w takim milczeniu i pokorze należy przyjmować wszelkie słowa obelżywe, aby przeciwnikowi nie wydawało się, że strona przeciwna zasłużyła na zniewage ${ }^{95}$.

- wolność, jest cnotą wewnętrzną ${ }^{96}$, bywa utożsamiana z duchową mądrością, wynika z przyjęcia zasad ewangelicznych i poznania Jezusa Chrystusa ${ }^{97}$ oraz z praktykowania cnót i wewnętrznej dyscypliny ${ }^{98}$. Wolność nie jest swawola, lecz możliwością robienia tego, co się chce, byle były to rzeczy dobre ${ }^{99}$. Duchowo przeżywana cnota wolności prowadzi ostatecznie do Boga i uwalnia człowieka z lęku przed śmiercia, gdyż człowiek wolny dba jedynie o osąd Boży ${ }^{100}$. W doczesności natomiast ludzie będąc posłuszni ludzkim prawom, stają się uczestnikami wolności obywatelskiej ${ }^{101}$, stąd Ambroży postulował ideę jedności społecznej i religijnej ${ }^{102}$.

\footnotetext{
${ }^{88}$ Por. tamże I 24, 105-115, SAEMO 13, 86-92, tłum. Abgarowicz, s. 56-59.

${ }^{89}$ Por. tamże I 2, 5-8, SAEMO 13, 24-26, thum. Abgarowicz, s. 20-22.

${ }^{90}$ Por. tamże I 3, 9-10, SAEMO 13, 26-28, tłum. Abgarowicz, s. 22-23.

${ }^{91}$ Por. tamże I 3, 11-13, SAEMO 13, 28, tłum. Abgarowicz, s. 23-24.

92 Por. tamże I 4, 14, SAEMO 13, 30, thum. Abgarowicz, s. 24.

${ }_{93}$ Por. tamże I 4, 15-16, SAEMO 13, 30, thum. Abgarowicz, s. 24-25.

${ }^{94}$ Por. tamże I 5, 17-20, SAEMO 13, 32.34, tłum. Abgarowicz, s. 25-26.

${ }^{95}$ Por. tamże I 6, 21-22, SAEMO 13, 34, tłum. Abgarowicz, s. 26-27.

${ }^{96}$ Por. Ambrosius, Epistula 7, 17, SAEMO 19, 80, BOK 9, 72.

${ }^{97}$ Por. tamże 7, 4, SAEMO 19, 74, BOK 9, 68.

${ }^{98}$ Por. tamże 7, 22, SAEMO 19, 84, BOK 9, 75

${ }^{99}$ Por. tamże 7, 19, SAEMO 19, 82, BOK 9, 73.

${ }^{100}$ Por. tamże 7, 45, SAEMO 19, 98, BOK 9, 84.
}

${ }^{101}$ Por. tamże 7, 32, SAEMO 19, 88, BOK 9, 79; więcej na ten temat zob. P. Nowak, Pojęcie wolności w Liście 7. św. Ambrożego z Mediolanu (do Symplicjana), VoxP 18 (1998) t. 34-35, 129134; J. Jurkiewicz, Ambrozjańska koncepcja wolności religii chrześcijańskiej w świetle relacji Ambrożego z Mediolanu z dworem cesarskim, Kraków 2006.

${ }^{102}$ Por. K. Ilski, Idea jedności politycznej, społecznej i religijnej w świetle pism Ambrożego 
- cnoty kardynalne: roztropność, sprawiedliwość, męstwo, umiarkowanie $^{103}$. Były już cechami patriarchów ${ }^{104}$. Roztropność jest źródłem obowiązków i zasila pozostałe trzy cnoty kardynalne. Natomiast podstawą wszystkich cnót, w ujęciu chrześcijańskim, jest miłość należna Bogu, potem ojczyźnie, rodzicom oraz wszystkim innym ${ }^{105}$. Sprawiedliwość łączy się z dobroczynnością, a obie te cnoty są podstawą życia społecznego, gdyż z nich wypływa prawo do wspólnej dla wszystkich własności, obowiązek niesienia sobie wzajemnej pomocy oraz zasada sprawiedliwości społecznej ${ }^{106}$. Zachowywanie cnoty sprawiedliwości zapewnia państwu siłę, życzliwość oraz miłość poddanych ${ }^{107}$. Podstawą sprawiedliwości, zdaniem Ambrożego, jest wiara ${ }^{108}$ (dla Cycerona ten sam termin łaciński, tj. fides oznaczał rzetelność, np. w dotrzymywaniu umów czy przyrzeczen ${ }^{109}$ ). Na dobroczynność składa się życzliwość i szczodrobliwość, sprawiedliwość oraz szczerośćc ${ }^{10}$. Odnośnie cnoty życzliwości, Ambroży zauważa, że dzięki niej wzrasta przynależność do Kościoła, wspólne dążenie do zdobywania cnót, kształtowanie podobnych charakterów ${ }^{111}$, życzliwość uśmierza też gniew, rodzi przyjaźń oraz zachęca do niesienia pomocy innym $^{112}$. Męstwo występuje łącznie z pozostałymi cnotami ${ }^{113}$, zależy od sił moralnych i fizycznych, a zadaniem człowieka mężnego jest opanowywanie wad i obrona słabych ${ }^{114}$. Męstwo zachęca chrześcijan do podobania się Bogu i do męczeństwa za wiarę 115 . To cnota, którą należy wzmacniać w przeciwnościach życiowych, przez bystrość umysłu, stałość moralna, uczciwą refleksję nad własnym postępowaniem oraz dążenie do wewnętrznej równowagi i spo$\mathrm{koju}^{116}$. Męstwo zwalcza też chciwość, gdyż sprzeciwia się niesprawiedliwej żądzy zysku i uleganiu namiętnościom ${ }^{117}$. Umiarkowanie, przejawia się w spokoju ducha, panowaniu nad sobą, zachowywaniu dobrych obyczajów ${ }^{118}$ oraz tego co stosowne (decorum) i godziwe (honestum) ${ }^{119}$.

\footnotetext{
z Mediolanu, Poznań 2001.

${ }^{103}$ Por. Ambrosius, De officiis ministrorum I 24, 115, SAEMO 13, 92, thum. Abgarowicz, s. 59.

${ }^{104}$ Por. tamże I 25, 116-121, SAEMO 13, 92-96, thum. Abgarowicz, s. 59-62.

${ }^{105}$ Por. tamże I 27, 126-129, SAEMO 13, 100-102, thum. Abgarowicz, s. 63-65.

${ }^{106}$ Por. tamże I 28, 130-136, SAEMO 13, 102-106, thum. Abgarowicz, s. 65-67.

${ }^{107}$ Por. tamże II 19, 95, SAEMO 13, 238, tłum. Abgarowicz, s. 144.

${ }^{108}$ Por. tamże I 29, 142, SAEMO 13, 108-110, thum. Abgarowicz, s. 69.

${ }^{109}$ Por. tamże, thum. Abgarowicz, s. 69, n. 163.

${ }^{110}$ Por. tamże I 30, 143-159, SAEMO 13, 110-118, thum. Abgarowicz, s. 70-75.

${ }^{111}$ Por. tamże I 33, 170-172, SAEMO 13, 126-128, thum. Abgarowicz, s. 80-81.

${ }_{112}$ Por. tamże I 34, 173-174, SAEMO 13, 128, thum. Abgarowicz, s. 81-82.

${ }^{113}$ Por. tamże I 35, 175-178, SAEMO 13, 130-132, thum. Abgarowicz, s. 82-83.

${ }^{114}$ Por. tamże I 36, 179-185, SAEMO 13, 132-136, thum. Abgarowicz, s. 83-86.

${ }_{115}$ Por. tamże I 37, 186-187, SAEMO 13, 136-138, thum. Abgarowicz, s. 86-87.

${ }_{116}$ Por. tamże I 38, 188-192, SAEMO 13, 138-140, thum. Abgarowicz, s. 87-88.

${ }_{117}$ Por. tamże I 39, 193-195, SAEMO 13, 140-142, thum. Abgarowicz, s. 89-90.

${ }_{118}$ Por. tamże I 43, 210-214, SAEMO 13, 150-152, thum. Abgarowicz, s. 95-96.

${ }^{119}$ Por. tamże I 45, 219-22 1 i I 47, 225-232, SAEMO 13, 154-158 i 160-162, thum. Abgarowicz,
} 
- pożyteczność; w ujęciu chrześcijańskim, zdaniem Ambrożego, jedynie to co moralnie dobre jest pożyteczne ${ }^{120}$. Mediolańczyk powtórzył tutaj za Cyceronem (officia perfecta, prima et officia media, secunda) ${ }^{121}$ stoicki podział obowiązków na doskonałe i zwyczajne ${ }^{122}$. Pożyteczny człowiek stara się o pożytek ogółu, na wzór Chrystusa, który przyjął ludzką naturę - człowieczeństwo, aby je wzbogacić przez uświęcenie ${ }^{123}$. Ambroży powtarza też tezę stoika Chryzyppa ${ }^{124}$, że bycie pożytecznym dla innych wypływa też z prawa naturalnego, któremu podlegają wszyscy ludzie, stąd nie powinni szkodzić swym bliźnim według natury, ale im pomagać ${ }^{125}$.

- uczciwość, jest przejawem mądrości, nawet w skrytości zachęca do dobrego postępowania, uchylającego się od haniebnych czynów, pomimo narażania się na niebezpieczeństwo ${ }^{126}$; stąd nie ma pożytku tam, gdzie uczciwość ponosi uszczerbek ${ }^{127}$. To cnota, która obowiązuje przyjaciół, a do obowiązków przyjaźni należy karcenie wad przyjaciela, szczerość, gotowość do usług i poświęceń, wierność, zgodny sposób myślenia, miłość nawet w wytykaniu błędów i bezinteresowność. Przyjaźń łączy człowieka z Bogiem i aniołami ${ }^{128}$.

- jałmużna, pojmowana jako wspomaganie biedniejszych wynikała dla Ambrożego z zasady ewangelicznego miłosierdzia i pomocy ludziom ubogim $^{129}$. Stąd jałmużna powinna być pomocą bezpośrednią wobec konkretnie jej potrzebujących ${ }^{130}$ : winna być dawana $\mathrm{z}$ hojnością, radością i pokorą ${ }^{131}$, a biedny ją otrzymujący ma obowiązek modlenia się za dobrodziejów ${ }^{132}$.

2. Wady społeczne: • egoizm, gdyż niszczy wszelkie działanie wspólnotowe, Ambroży przeciwstawia wadzie egoizmu idealny obraz winnicy, będącej wyobrażeniem współpracy w Kościele ${ }^{133}$.

- pycha, będąc nieposłuszeństwem wobec Boga, kształtuje ludzi w złych

\footnotetext{
s. $97-98$ i 101.

${ }^{120}$ Por. tamże III 14, 88, SAEMO 13, 326, thum. Abgarowicz, s. 194.

${ }^{121}$ Por. tamże, thum. Abgarowicz, s. 167, n. 21.

${ }^{122}$ Por. tamże III 2, 8-13, SAEMO 13, 278-282, thum. Abgarowicz, s. 166-169.

${ }^{123}$ Por. tamże III 3, 15-16, SAEMO 13, 282, thum. Abgarowicz, s. 169.

${ }^{124}$ Por. tamże, tłum. Abgarowicz, s. 173, n. 45.

${ }^{125}$ Por. tamże III 4, 24-28, SAEMO 13, 286-290, thum. Abgarowicz, s. 172-174.

${ }^{126}$ Por. tamże III 5, 29-35, SAEMO 13, 290-294, tłum. Abgarowicz, s. 174-177.

${ }^{127}$ Por. tamże III 6, 37-44, SAEMO 13, 296-300, tłum. Abgarowicz, s. 177-179.

${ }^{128}$ Por. tamże III 22, 126-138, SAEMO 13, 350-356, tłum. Abgarowicz, s. 207-211.

${ }^{129}$ Ambrosius, De Nabuthae 14, 58 oraz 7, 33 i 36-37, SAEMO 6, 178 oraz 154 i 156-158, PSP 35, 47 i 36-38.

${ }^{130}$ Por. Ambrosius, De officiis ministrorum I 30, 143, SAEMO 13, 110, thum. Abgarowicz, s. 70.

${ }^{131}$ Por. Ambrosius, De Nabuthae 8, 40, SAEMO 6, 160-162, PSP 35, 39-40.

132 Por. Ambrosius, De Nabuthae 14, 58-60 i 16, 66-67, SAEMO 6, 178-180 i 188-190, PSP 35 , 47-48 i 51-52.

${ }^{133}$ Por. Ambrosius, Exameron III 12, 51; V 1, 2 i VI 8, 51, SAEMO 1, 162-164 oraz 236-238 i 396, PSP 4, 102-103, 139-140 i 213-214.
} 
wyborach, upodabnia do diabła i doprowadza do niesprawiedliwości wobec ludzi i do śmierci ${ }^{134}$; pycha jest u początków grzechu, dlatego chce wykrzywić każde dobro ${ }^{135}$; ukrywa każde zło i odwodzi ludzi od przyznania się do winy i pokuty za grzechy ${ }^{136}$; odwodzi człowieka od uznawania autorytetu Boga, zakłamuje prawdę i jest wroga uczciwości ${ }^{137}$; wyrabia u ludzi fałszywe poczucie wyższości nad innymi ${ }^{138}$; ludzie pełni pychy stale chwalą swoje postępowanie przed innymi, będąc $\mathrm{w}$ tym samym czasie aroganccy, obrażający innych, szczególnie ubogich ${ }^{139}$. Pycha jako podstawa i substancja grzechu pierwszych ludzi, prowadząc do niesprawiedliwości, zwodzi wcześniej fałszem, wpływa na ludzkie słabości i doprowadza do przekraczania granic wyznaczonych człowiekowi przez Boga ${ }^{140}$. Pycha obraża i neguje prawdę ${ }^{141}$; zaciemnia intelekt człowieka i jego wrażliwość uczuciową, wzbudzając zazdrość i brak miłosierdzia ${ }^{142}$. Pycha nie znosi pokory, dlatego - przez ludzką mądrość i intelekt cielesny (łac. humana sapientia mens carnis) chwali wszystko co jest odwrotnością cnoty, doprowadzając do degradacji człowieczeństwa ${ }^{143}$. Szczególnie atakuje mądrość, dlatego Ambroży zaleca ludziom mądrym pokorę, na wzór pokory świętego króla Dawida czy świętego patriarchy Józefa ${ }^{144}$.

- chciwość, wynika ze złego używania dóbr materialnych, gdyż stanowi przejaw bałwochwalstwa człowieka wobec materii oraz sprzeciw chciwca wobec woli Stwórcy o powszechnym przeznaczeniu dóbr materialnych dla wszystkich ludzi ${ }^{145}$. Chciwość i żądza władzy wypaczają i osłabiają sprawiedliwość społeczną ${ }^{146}$. Chciwość jest prastarą wadą niszczącą nie tylko pojedynczych ludzi, ale i wiele starożytnych miast ${ }^{147}$. Stąd Ambroży przestrzegał, by nie naruszać depozytów, szczególnie tych należących do wdów i bronić ich nawet przed chciwymi zakusami rządzących ${ }^{148}$. Przestrzegał przed popełnianiem z chciwości wszelkiego oszustwa, które jest zawsze karygodne i niedozwolone, gdyż niszczy ono umowę społeczną o zachowywaniu wzajemnej

\footnotetext{
${ }^{134}$ Por. Ambrosius, Expositio Psalmi 118, 3, 34, SAEMO 9, 158.

${ }^{135}$ Por. tamże 3, 35, SAEMO 9, 158-160.

${ }^{136}$ Por. tamże 15, 31, SAEMO 10, 164.

${ }^{137}$ Por. tamże 16, 15, SAEMO 10, 184.

${ }^{138}$ Por. tamże 3, 36, SAEMO 9, 160.

${ }^{139}$ Por. tamże 3, 37, SAEMO 9, 160.

${ }^{140}$ Por. tamże 7, 8, SAEMO 9, 280.

${ }^{141}$ Por. tamże 7, 9, SAEMO 9, 280.

${ }_{142}$ Por. tamże 9, 18, SAEMO 9, 394.

${ }^{143}$ Por. tamże 14, 20, SAEMO 10, 104.

${ }^{144}$ Por. tamże 14, 21, SAEMO 10, 106.

${ }^{145}$ Por. Ambrosius, De Nabuthae 1, 1; 3, 11; 6, 29 i 7, 35, SAEMO 6, 130, 138, 152 i 156, PSP

${ }^{146}$ Por. Ambrosius, De officiis ministrorum I 28, 137-138, SAEMO 13, 106, thum. Abgarowicz,

${ }^{147}$ Por. tamże II 26, 129-132, SAEMO 13, 256-258, thum. Abgarowicz, s. 155-156.

${ }^{148}$ Por. tamże II 29, 144-151, SAEMO 13, 264-270, thum. Abgarowicz, s. 160-162.
} 35, 26, 29, 35 i 37. s. 67. 
uczciwości i niewyrządzaniu sobie zła, także w handlu ${ }^{149}$. Dlatego każdy rodzaj oszustwa jest zabroniony, zarówno przez umowę ludzką jak i objawienie Boże ${ }^{150}$. Napominał duchownych, by unikali chciwości, nie zabiegali o spadki pod pozorem bezinteresowności i stateczności, oraz aby nie wyłudzali podstępnie i posługując się kłamstwem pieniędzy innych ${ }^{151}$. Tego typu chciwość Ambroży z Mediolanu nazywał haniebnym oszustwem, które będzie ukarane przez Boga, gdyż, ,jeżeli na targu, w stosunkach handlowych, karze się oszustwo, czy może ono pozostać bez nagany w życiu tych, którzy obowiązani są starać się o nabycie cnót? Wołał Salomon: «Waga wielka i waga mała, miara dwojaka, obie obrzydłe są Panu» (Prz 11, 1). Poprzednio również zapewniał: «Obrzydła dla Jahwe waga fałszywa, upodobaniem Jego - ciężarek uczciwy» (Ps 14, 3)" "152.

- lichwa, była odrzucana przez Ambrożego jako plaga społeczna ${ }^{153}$, gdyż stanowiła niegodny dochód, krzywdzący pożyczkobiorcę ${ }^{154}$ oraz była praktyką niemoralną, bo bazującą na oszustwie w posługiwaniu się pieniądzem ${ }^{155}$. Dlatego stwierdzał, że działaniem nieuczciwym, bo wynikającym z chytrości jest podwyższanie cen i przetrzymywanie np. zboża w celach spekulacyjnych ${ }^{156}$.

- niegodziwość, jest nią np. wypędzanie $\mathrm{z}$ miasta obcych (w domyśle: nie-Rzymian, nieobywateli) w czasie głodu w okresie oblężenia. Zrywało się w ten sposób więzy rodzinne, towarzyskie, niczego w zamian się nie zyskując, ulga była pozorna, bo dawała dodatkową żywność na kilka dni, lecz powiększyła ogół cierpień ${ }^{157}$. Dlatego stwierdzał „to co godziwe, jest zarazem pożyteczne, a co pożyteczne, tym samym godziwe. I na odwrót, co szkodliwe, to niestosowne, co zaś niestosowne, to także szkodliwe" 158 .

- obietnica dokonania zlego czynu, nie obowiązuje nawet wtedy, gdy została złożona pod przysięga, gdyż nie wynika z naturalnego i szczerego usposobienia człowieka, nie wyraża prostoty słowa i czystości czynu, ale zwodzi bliźniego fałszywym słowem, obiecuje co jest niegodziwe i hańbiące spraw$\mathrm{cę}^{159}$. Ambroży zalecał, by nie składać takich obietnic, a już przyrzeczonych - nie dotrzymywać, gdyż inaczej można paradoksalnie popaść w złożenie

\footnotetext{
${ }^{149}$ Por. tamże III 10, 66-69, SAEMO 13, 312-316, thum. Abgarowicz, s. 186-188.

${ }^{150}$ Por. tamże III 11, 70-75, SAEMO 13, 316-318, tłum. Abgarowicz, s. 188-190.

${ }^{151}$ Por. tamże III 9, 57-66, SAEMO 13, 308-312, thum. Abgarowicz, s. 183-186.

${ }_{152}$ Por. tamże III 9, 65, SAEMO 13, 312, tłum. Abgarowicz, s. 186.

${ }^{153}$ Por. Ambrosius, De Tobia 8, 29-31 i 10, 36, ed. C. Schenkl - F. Gori, SAEMO 6, 224-226 i 230-232, thum. J. Jundziłł, PSP 35, Warszawa 1986, 92-93 i 94.

${ }^{154}$ Por. tamże 13, 43, SAEMO 6, 238-240, PSP 35, 98-99.

${ }^{155}$ Por. tamże 2, 7; 4, 12; 16, 54, SAEMO 6, 202, 208, 252, PSP 35, 83-85 i 104-105.

${ }^{156}$ Por. Ambrosius, De officiis ministrorum III 6, 37 i 41, SAEMO 13, 296 i 298-300, thum. Abgarowicz, s. 177-179.

${ }^{157}$ Por. tamże III 7, 45-51, SAEMO 13, 302-306, tłum. Abgarowicz, s. 180-182.

${ }^{158}$ Por. tamże III 7, 52, SAEMO 13, 306, thum. Abgarowicz, s. 182.

${ }^{159}$ Por. tamże III 12, 76, SAEMO 13, 320, thum. Abgarowicz, s. 190.
} 
nierozważnej przysięgi prowadzącej do zguby swoich bliskich, jak np. wódz Jefte, który przyrzekł, że po zwycięstwie złoży Bogu w ofierze całopalnej cokolwiek, co po jego powrocie pierwsze ukaże się mu na progu jego domu. I na spotkanie ojca - wyszła jego własna córka (por. Sdz 11, 31-34). Stąd Biskup Mediolanu stwierdzał: „Lepiej niczego nie przyrzekać niż dawać takie przyrzeczenie, którego dotrzymania nie życzy sobie ten, komu się je składa"160.

Ambrozjańskie ujęcie cnót i wad nie było jeszcze kompletną chrześcijańską teorią cnót i wad, a tym bardziej jakichś ich odniesień społecznych, gdyż w IV wieku brakowało jeszcze do jej pełności szeregu elementów teologicznych. Jak wykazuje Klaus Zelzer, początki kompletnej teorii cnót chrześcijańskich można zaobserwować dopiero wraz z teologią monastyczną Grzegorza Wielkiego, który na bazie tradycji ascetycznej połączył cztery cnoty kardynalne i trzy cnoty teologalne z koncepcją siedmiu darów Ducha Świętego. O jedności siedmiu cnót moralnych nauczał od XII wieku Piotr Lombard, a pełen wykład systematycznej teorii cnót moralnych podał św. Tomasz z Akwinu w Sumie Teologicznej 2, $2^{161}$.

Rozproszone w dziełach Ambrożego uwagi na temat życia społecznego chrześcijan tworzą w miarę spójny obraz poglądów duszpasterskich Doktora z Mediolanu. W kontekście refleksji teologicznych jego rozważania dotyczące małżeństwa i rodziny, pracy i własności oraz cnót i wad posiadają zawsze odniesienie teleologiczne. Celem każdego działania człowieka w społeczności ludzkiej ostatecznie zawsze jest Bóg. Mówiąc o małżeństwie i rodzinie konsekwentnie prezentowania argumentacja teleologiczna doprowadziła Ambrożego do podwójnej perspektywy ujmowania małżeństwa: pozytywnej i negatywnej oraz koncepcji wyższości funkcjonalnej tego co męskie nad tym co kobiece. Pełne wyzwolenie obu płci nastąpi dopiero w wieczności, natomiast w doczesności emancypacja natury kobiecej może mieć miejsce dzięki uświęceniu poprzez religię chrześcijańską, a także poprzez pełnienie roli żony, matki, a także poprzez zachowanie dziewictwa konsekrowanego.

Poruszając tematykę pracy ludzkiej Ambroży również umieszczał ją w perspektywie religijnej: od raju, upadku w grzech do ostatecznego wyzwolenia człowieka w zbawieniu. Praca przynależy do natury człowieka od momentu jego stworzenia jeszcze przed grzechem pierwszych ludzi. Po grzechu staje się ona zarówno karą za grzech (stą trud i ból), ale także narzędziem do zbawienia (sposobem odkupienia win) oraz środkiem koniecznym do zapewnienia koniecznych potrzeb i środkiem do udoskonalania człowieka poprzez osiągnięcie cnót moralnych. Ambroży doceniał wszystkie rodzaje pracy (fizyczną/

\footnotetext{
${ }^{160}$ Por. tamże III 12, 79, SAEMO 13, 322, thum. Abgarowicz, s. 191.

${ }^{161}$ Por. Zelzer, L'etica di Sant'Ambrogio, s. 55.
} 
manualną, intelektualna, apostolska), bronił prawa do sprawiedliwego wynagrodzenia za pracę oraz prawa do wypoczynku. Ideałem pracy w społeczności była dla Mediolańczyka solidarna praca zespołowa.

Ambroży uznawał prawo do własności indywidualnej oraz własności wspólnotowej. Ujęcie prawa własności miało również charakter religijny. Własność dóbr ziemskich również była odnoszona do celu religijnego, jakim ostatecznie zawsze jest Bóg. Stąd prawo własności jest ograniczone w rozumieniu i zastosowaniu: przez cel (Bóg), czas użytkowania (doczesność), intencje Ostatecznego Właściciela (dobro wszystkich ludzi), Boże plany wobec każdego człowieka (sprawiedliwość, braterstwo, solidarność, wzajemną miłość).

Biskup Mediolanu wprowadził również do chrześcijańskiej teologii moralnej system oceny czynów ludzkich według stoickiej kategorii cnót i wad. Ten schemat stoicki został połączony przez Ambrożego z alegoryczną koncepcją czterech rzek prowadzących do raju Filona z Aleksandrii oraz teologią moralną św. Pawła apostoła. Na drodze do Boga podstawowymi cnotami dla chrześcijanina powinny być pokora i bojaźń Boża. One dopiero prowadzą do właściwej mądrości i błogosławieństwa, czyli do poznania Boga i do nieba. Na tej drodze do wieczności w doczesności chrześcijanin żyjąc wśród innych ludzi winien kierować się obowiązkowością, milczeniem, wolnością, cnotami kardynalnymi, pożytecznością tego co robi, uczciwością oraz dawaniem jałmużny. W życiu społecznym wierzący winien wystrzegać się szczególnie wady egoizmu i pychy, ale także lichwy, chciwości, niegodziwości oraz składania nieroztropnych obietnic.

Tematyka społeczna poruszana w pismach duszpasterskich św. Ambrożego była zawsze podporządkowana celowi teologicznemu. Biskup Mediolanu starał się tak kierować życiem chrześcijan, aby w codziennych okolicznościach życia, w małżeństwie i rodzinie, w stanie życia konsekrowanego, w pracy i każdym innych spotkaniu z drugim człowiekiem, wierzący zawsze motywował swe działania wyborem Boga i podążaniem za Jego wskazaniami. Ambroży nie opracował syntezy zachowań moralnych życia chrześcijańskiego w społeczeństwie, ale w swoich poglądach poruszył wiele wątków, które z czasem posłużyły innym, jak Piotr Lombard czy Tomasz z Akwinu do opracowania spójnego systemu życia moralnego w kategoriach cnót i wad. Zasługą Ambrożego było niewątpliwie umiejętne połączenie dorobku filozofii stoickiej i myśli Filona Aleksandryjskiego z teologią moralną św. Pawła. 


\section{SOCIAL ISSUES IN THE WRITINGS OF SAINT AMBROSE OF MILAN}

\section{(Summary)}

Numerous remarks which refer to the Christian social life in the writings of St Ambrose (339-397) offer us a relatively homogeneous picture of his pastoral opinions on marriage and family, work, property and virtues as considered in the theological context. God is the single aim of every man's activity in the social activities. A systematic theological analysis led St. Ambrose to the conclusion that: 1) Marriage can have either a positive or negative sense and 2) that the male component in marriage is dominant over the female. He argued that the full liberation of both sexes would come only in Eternal Life. The emancipation of women is possible in this world through the Christian religion, through the role of a wife, mother or the consecrated virginity. Labor is inseparately related to human nature from its creation and before original sin. After original sin, human labor changed in the punishment for sin (pain and hardship) however in the same time became the means of salvation, and the redemption of sins. It is also necessary to sustain living and gives a chance to achieve moral virtues. Work and mutual assistance were made by the Bishop of Milan a model work in the society. St Ambrose accepted both private possession rights and a community property of goods. The earthly goods should be used always with the religious perspective of the sole destiny - God. The main Aim-God, a temporary possession of goods (worldliness) and the purpose of the Main Owner- the good of every man (justice, fraternity, solidarity, mutual love) are the limits of a possession rights. The Bishop of Milan also introduced to the Christian moral theology the system of evaluation of the human deeds based on the Stoic categories of virtues and vices. St. Ambrose combined this system with the allegoric conception of the Four Rivers of the Philo of Alexandria and St. Paul's moral theology. A Christian should be guided by the virtues of humbleness and fear of God. They will lead him to the wisdom and divine blessing, subsequently to the real knowledge of God. In this world the Christians should respect the sense of responsibility, the virtue of silence, freedom, cardinal virtues, honesty, charity and usefulness of his work. In the social life Christians are obliged to denounce the vices of egoism and arrogance, usury, greediness, vice behavior or giving unwise promises. The social problems were always subordinated to the theological purposes in the writings of St. Ambrose. The Christian are always obliged to be guided by Gods Commandments. St. Ambrose did not manage to work out a code of Christian moral behavior in a society, however he discussed many different problems, which were used by others (cf. St. Thomas of Aquino) to construct such a code. A synthesis of the Stoic philosophy, the philosophy of Philo Judaeus and St. Paul's moral theology can be legitimately regarded as his valuable contribution to the studies of ethics. 